\title{
Homeric Rewriting in Greek Sirach
}

\author{
James K. Aitken \\ Faculty of Divinity, University of Cambridge \\ jka12@cam.ac.uk
}

\begin{abstract}
It has been recognized in recent scholarship that the Greek translation of Sirach is subtle in its use of word-play and inner-Greek allusion. One such case, the story of the wandering man in Sir (31)34:9-13, can be shown to be a narration of two types of person, the one who wanders for positive learning and the one who errs and is in danger of death. It is thus not the personal experience of the author who has the freedom to travel in the new Hellenistic empires, but a moral tale modelled upon the two types of Odysseus that developed in the Greek tradition. This demonstrates the crafting of the source by the translator on the discourse level and hints at his educational background. It also has consequences for the larger structure of the unit in Sirach and further undermines the idea of a personal biography of Ben Sira.
\end{abstract}

\section{Keywords}

Sirach - Septuagint - Homer - Odysseus - travel

\section{$1 \quad$ Introduction}

Greek Sirach has been poorly served by its interpreters. Its consistent translation technique has led to its being largely ignored for the contribution it can make to translation studies and for the important place it occupies in the history of Septuagint studies. Thackeray set the agenda by classifying the translation as "indifferent Greek," conflating translation technique with Greek register.

1 Henry St.-J. Thackeray, Introduction, Orthography and Accidence. Vol. 1 of A Grammar of the Old Testament in Greek According to the Septuagint (Cambridge: Cambridge University Press, 1909), § 2 . 
Others have prioritized the isomorphic nature of the Greek translation, noting how it renders at the word level rather than the phrase or clause level. ${ }^{2}$ This is despite the recognition that the Greek does not represent the Hebrew precisely. ${ }^{3}$ Hence, the prime characteristic of the Greek is said to be the interference displayed from the Hebrew in those places where the translator has privileged the source text over natural Greek usage. ${ }^{4}$

These assessments of the translation have been dominant despite the fact that the translator famously left a preface that demonstrates not only a sophisticated command of Greek in its very writing, ${ }^{5}$ but significantly provides one of the first reflections on translation method in antiquity. One option, therefore, is to conclude that the translation must reflect a departure from the literary style of the preface and should be labelled as translation Greek. ${ }^{6}$ This renders the preface as a mere apology for the translation, but it does not account for the rhetoric of the preface and its potentially significant discussion of translation method. ${ }^{7}$ However, another possibility, if we take his reflections on translation seriously, is to show the degree of sophistication in the translation, both in its semantics and in the sound of the Greek. Recent scholarship has indicated how the Greek is sensitive to the rhetorical effect, is subtle in its translation choices, and chooses words of a literary register. ${ }^{8}$ These literary

2 See, e.g., Benjamin G. Wright, "Translation Greek in Sirach in Light of the Grandson's Prologue," in The Texts and Versions of the Book of Ben Sira: Transmission and Interpretation, ed. J.-S. Rey and J. Joosten, JSJSup 150 (Leiden: Brill, 2011), 90-93.

3 Benjamin G. Wright, No Small Difference. Sirach's Relationship to its Hebrew Parent Text, scss 26 (Atlanta, GA: Scholars Press, 1989), 115.

4 Wright, "Translation Greek," 91-92.

5 See James K. Aitken, "The Literary Attainment of the Translator of Greek Sirach," in The Texts and Versions of the Book of Ben Sira: Transmission and Interpretation, ed. J.-S. Rey and J. Joosten, JSJSup 15o (Leiden: Brill, 2011), 95-126; id., "The Literary and Linguistic Subtlety of the Greek Version of Sirach," in Texts and Contexts of the Book of Sirach/Texte und Kontexte des Sirachbuches, ed. G. Karner, F. Ueberschaer, and B. M. Zapff (Atlanta, Ga.: sBL Press, 2017), 115-40. Wright, No Small Difference, also recognized that there was variety in the choice of equivalents.

6 Benjamin G. Wright, "Why a Prologue? Ben Sira's Grandson and His Translation," in Emanuel: Studies in Hebrew Bible, Septuagint and Dead Sea Scrolls in Honor of Emanuel Tov, ed. S. M. Paul et al., vTs 94 (Leiden: Brill, 2003), 633-44; Wright, "Translation Greek," 76.

7 On the rhetoric of the preface, see Aitken, "Literary Attainment," 101-8. For a recent discussion of translation theory in the preface, see Ekaterina Matusova. "The Origins of Translation Theory: The Lxx among Jewish Greek Writers," in Die Septuaginta-Geschichte, Wirkung, Relevanz. 6. Internationale Fachtagung veranstaltet von Septuaginta Deutsch (LXX.D), Wuppertal 21.-24. Juli 2016, ed. Martin Meiser, Michaela Geiger, Siegfried Kreuzer and Marcus Sigismund, wUNT 405 (Tübingen: Mohr Siebeck, 2018), 557-72.

8 Aitken, "Literary Attainment"; Aitken, "Literary and Linguistic." 
modifications are sufficient alone to demonstrate the creativity of the translator at his desk. ${ }^{9}$ They also confirm the difficulty in reconstructing the Hebrew source text where it is lacking. ${ }^{10}$ The attention in this paper will be placed on one passage that reveals a shaping by the translator to a greater extent than even those literary aspects might imply. He adapts his source text to create a popular image from classical literature, and through literary allusion crafts a new meaning for the passage. It will show how a Jewish translator could adapt a classical theme successfully for expression of Jewish theology.

The short passage Sir 31(34):9-13 is nestled between advice against trusting in dreams (31[34]:1-8) and a poem on trusting in the Lord (31[34]:14-20). It is conventional to take the passage as a description of the benefits of travel combined with an autobiographical statement by Ben Sira on the advantages he himself has gained from travelling. It is thereby said to connect with Sir 39:4 and 51:13a that equally seem to refer to such travel of the sage. ${ }^{11}$ The passage begins in the third person, offering gnomic sentiments on wisdom gained from such activity:

9 See too Ruth Scoralick, “Dann wirst du für den Höchsten wie ein Sohn sein' (Sir 4,10): Armenethos und Gottesnähe in Sir 4,1-10," in Mehr als zehn Worte? Zur Bedeutung des Alten Testaments in ethischen Fragen, ed. Ch. Frevel, QD 273 (Freiburg: Herder, 2015), 263-85. A small interpretative example is also demonstrated by Jan Joosten, "A Gift of Arms': The Greek Translation of Sirach 7:31 and the Interpretive Process Underlying the Septuagint," in The Faces of Torah: Studies in the Texts and Contexts of Ancient Judaism in Honor of Steven Fraade, ed. Michal Bar-Asher Siegal, Tzvi Novick, and Christine Hayes, Journal of Ancient Judaism Supplements 22 (Göttingen:Vandenhoeck \& Ruprecht, 2017), $131-38$.

10 Recently emphasized by Wright in "Sirach 10.1-18: Some Observations on the Work of the Translator," in Texts and Contexts of the Book of Sirach. Texte und Kontexte des Sirachbuches, ed. Gerhard Karner, Frank Ueberschaer and Burkard M. Zapff, sBLscs 66 (Atlanta, GA: SBL, 2017), 163-88.

11 Some also invoke also invoke Sir 29:21-28 as a travel passage. See Norbert Peters, Das Buch Jesus Sirach oder Ecclesiasticus (Munster: Aschendorff, 1913), 241; P. C. Beentjes "The Concept of Brother in the Book of Ben Sira: A Semantical and Exegetical Investigation," in Treasures of Wisdom: Studies in Ben Sira and the Book of Wisdom. Festschrift M. Gilbert, ed. N. Calduch-Benages and J. Vermeylen, BETL 143 (Leuven: Peeters, 1999), 84. 


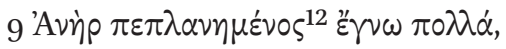

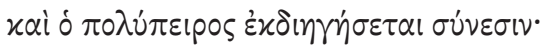

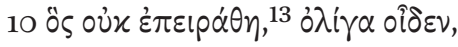

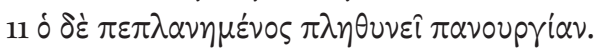

9 A man that is a wanderer knows many things,

and the one who is much experienced will recount his understanding.

10 He who has no experience knows few things,

11 and the one who is a wanderer will increase trickery.

The traditional interpretation of this passage is that it is on the theme of learning from travels. ${ }^{14}$ The NRSV is explicit in its connection with travel, rendering verse 11 as "but he that has traveled acquires much cleverness."15 The Septuaginta Deutsch offers similar with its translation "gereist ist."16 The translation given here prefers a more neutral sense of "to wander," which is similar to NETS with its rendering "roamed" for the participle $\pi \varepsilon \pi \lambda \alpha \nu \eta \mu \varepsilon$ vo

The passage continues in the first person, where the author reveals his own experience:

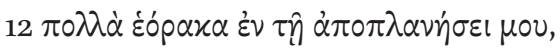

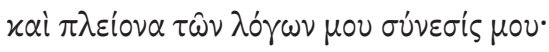

$13 \pi \lambda \varepsilon \circ \nu \alpha \dot{\alpha}$ «

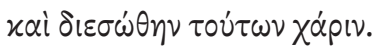

12 The reading $\pi \varepsilon \pi \alpha \iota \delta \varepsilon u \mu \varepsilon \dot{v}{ }^{\prime} \varsigma$ is found Codices A and B, one Origenic manuscript, some Lucianic manuscripts, and in some minor versions. Patrick W. Skehan and Alexander A. Di Lella, The Wisdom of Ben Sira, AB 39 (New York: Doubleday, 1987) prefer $\pi \varepsilon \pi \alpha \iota \delta \varepsilon \cup \mu \varepsilon \dot{v} \circ \varsigma$, but Ziegler adopts $\pi \varepsilon \pi \lambda \alpha \nu \eta \mu \varepsilon \dot{v} \circ \varsigma$ (J. Ziegler, Sapientia Iesu Filii Sirach [Septuaginta: Vetus Testamentum Graecum 12:2; Gôttingen: Vandenhoeck und Ruprecht, 1965], 409). It seems that a misunderstanding of $\pi \varepsilon \pi \lambda \alpha \nu \eta \mu \varepsilon$ vos as negative led to the change to $\pi \varepsilon \pi \alpha \iota \delta \varepsilon u \mu \varepsilon \dot{\varepsilon} \sim \varsigma$, a change that is unlikely to have happened in reverse. See

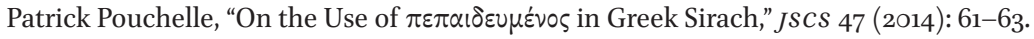

13 The alternative form of $\dot{\varepsilon} \pi \varepsilon ı \dot{\alpha} \sigma \theta \eta$ from the verb $\pi \varepsilon ı \rho \dot{\zeta} \zeta \omega$ appears in Codex Sinaiticus and some other witnesses, but H. St. J. Thackeray makes clear that the active meaning establishes the form given in the text here (A Grammar of the Old Testament in Greek [Cambridge; Cambridge University Press, 1909], 221).

14 E.g., A. Eberharter, Das Buch Jesus Sirach oder Ecclesiasticus, Die Heilige Schrift des Alten Testamentes ubersetzt und erklärt in Verbindung mit fachgelehrten 6, 5 (Bonn: P. Hanstein. 1925); 118; Georg Sauer, Jesus Sirach, Ben Sira: übersetzt und erklärt, ATD Apokryphen 1 (Göttingen: Vandenhoeck \& Ruprecht, 2000), 241.

15 In the NRSV verse 9 is translated as "An educated person," following the variant $\pi \varepsilon \pi \alpha 1 \delta \varepsilon \cup \mu \varepsilon \dot{v} \circ \varsigma$.

16 Wolfgang Kraus und Martin Karrer, eds, Septuaginta Deutsch: Das griechische Alte Testament in deutscher Übersetzung (Stuttgart: Deutsche Bibelgesellschaft, 2009), 1137. 
12 Many things I have seen in my diversions, and far more than my words is my understanding. 13 many times I was in danger of death, and I was saved because of these things.

The NETS translation now speaks of "wandering" ( $\dot{\alpha} \pi \circ \pi \lambda \dot{\alpha} \nu \eta \sigma / \zeta)$ as the verbal action, while the NRSV continues its theme with the noun "travels" (cf. LXX Deutsch: "meinen Reisen"). When understood as a passage on traveling, it has been seen as important in the reconstructing of the author's social world and the influences upon him. It is a parade example of the new type of sage that is typified in Ben Sira, open to the wider world afforded by the new Hellenistic empires and able to visit foreign courts and high officials. ${ }^{17}$ For some it is evidence that Ben Sira is open to other cultures, willing to visit and learn from them, and therefore it serves as an important bridge for him to the Hellenistic world. ${ }^{18}$ Others have also drawn parallels to Greek itinerary accounts so that the literary form is itself an indicator of that bridge between cultures. ${ }^{19} \mathrm{In}$ other words, the travelling is expressive of an openness to Greek culture and this very openness is revealed in the use of a Greek literary form of travel narrative. Once seen in this light, the dangers in verse 13 that Ben Sira says he experienced are understood to be the natural dangers facing any traveller in the ancient world, including the risks of theft, shipwreck or physical harm. ${ }^{20}$ Skehan and Di Lella even include within such dangers the traveller's stomach bugs: "One had to cope with disease and discomfort, which a change in food and water can occasion"-perhaps reminiscent of more modern concerns than that of an ancient traveller.

17 Rudolf Smend, Die Weisheit des Jesus Sirach, erklärt (Berlin: Reimer, 1906), lxiv; Martin Hengel, Judaism and Hellenism: Studies in their Encounter in Palestine during the Early Hellenistic Period, trans. John Bowden (London: SCM, 1974), 1: 132-33; Johannes Marböck, Weisheit im Wandel: Untersuchungen zur Weisheitstheologie bei Ben Sira (Bonn: Hanstein, 1971), 161-62; H. Stadelmann, Ben Sira als Schriftgelehrter, wunt 6 (Tübingen: Mohr-Siebeck, 1980), 229-3o.

18 Theophil Middendorp, Die Stellung Jesu Ben Siras zwischen Judentum und Hellenismus (Leiden: Brill, 1973), 170-73; Nuria Calduch-Benages, "Elementos de inculturación helenista en el libro de Ben Sira," EstBib 54 (1996): 289-98; Jean-Jacques Lavoie, "Ben Sira le voyageur ou la difficile recontre avec l'hellénisme," Science et Esprit $5^{2}$ (2000): 37-6o.

19 Calduch-Benages, "Elementos," 298.

20 See, e.g., Skehan and Di Lella, Wisdom, 409-10. For Calduch-Benages, the importance of the reality of the trials faced by the traveller is deliberately contrasted with the fantasies of the dreams mentioned before. See N. Calduch-Benages, "Trial Motif in the Book of Ben Sira with Special Reference to Sir 2,1-6," in The Book of Ben Sira in Modern Research: Proceedings of the First International Ben Sira Conference, July 1996, Soesterberg, Netherlands, ed. Pancratius C. Beentjes (Berlin: de Gruyter, 1997), 145-47. 
The assumption of a concrete historical situation behind this passage, and the consequent reconstruction of the life of an ancient sage, have not allowed room for consideration of the literary form of the passage. Indeed, the assumption of a particular historical context has obscured the meaning of the words and the subtlety in the lexical choices. If the passage is read on its own terms, and the words are considered without imposing a preconceived interpretation of the travelling sage, a different orientation can be seen. The resulting selfpresentation of the passage, its internal literary logic, offers a different meaning from the reconstructed persona of Ben Sira in scholarly discussions..$^{21}$ One difficulty is that the passage is only extant in Greek, but scholars have failed to make sufficient distinction between the contents of the Greek and what might have existed in the putative Hebrew Vorlage. The Greek reflects features of a literary development internal to it and impossible to reproduce in Hebrew. ${ }^{22}$

\section{3} Literary Features of the Passage

Certain literary features of the passage highlight the careful structuring by the translator and suggest that the words have been subtlely chosen by the translator rather than selected as default renderings of the Hebrew. Words beginning with the letter $p i$ are a popular rhetorical technique of the Sirach translator, ${ }^{23}$ and are not accidental if verse 11 is an indication: $\delta$ $\delta \dot{\varepsilon} \pi \varepsilon \pi \lambda \alpha \nu \eta \mu \varepsilon \dot{v} 0 \varsigma \pi \lambda \eta \theta u v \varepsilon \hat{\imath}$ $\pi \alpha$ voupriav. Words with $p i$ also open verses 12,13 , and 14 so that there is a strong sense of this sound throughout this passage and continuing into the "autobiographical" section. Also noticeable in the passage is the emphasis upon many

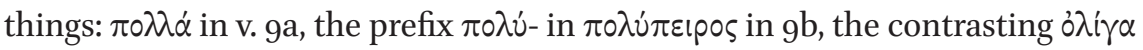
"few" in 1oa and then the "increasing" $\pi \lambda \eta \theta u v \varepsilon \hat{~ i n ~ 1 o b . ~ T h e s e ~ a r e ~ p i c k e d ~ u p ~ i n ~}$ the following "autobiographical" section with $\pi 0 \lambda \lambda \dot{\alpha}$ in 11a, $\pi \lambda \varepsilon$ Eiov $\alpha$ in 11b, and $\pi \lambda \varepsilon o v \alpha$ x 1 s in 12a. There is also the distinctive vocabulary of the translator, opting for rare words that are only occasionally used by other translators of sapiential literature: the rare adjective $\pi \circ \lambda v^{\pi} \varepsilon i p o \varsigma$ "with much experience" 24 and the compound $\pi$ avoupria "cleverness," appearing in Sirach four times (elsewhere at 19:23, 25; 21:12) though popular in LXx Proverbs as well.

21 See Jacqueline Vayntrub, "The Book of Proverbs and the Idea of Ancient Israelite Education," ZAW 128 (2016): 100-1.

22 As noted by Aitken, "Literary and Linguistic," 137-39.

23 See Aitken, "Literary Attainment," 120.

24 Cf. Aitken, "Literary Attainment," 109. 
More significant is the intentional repetition of words from the same root often with subtle changes in sense, a technique found in accomplished writers. ${ }^{25}$ As mentioned above, this passage is preceded by a warning on the dangers of following dreams and omens. That pericope ends with the words:

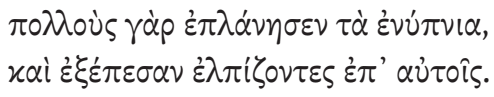

For dreams have deceived many, and persons who hope in them have fallen.

Sir 31[34]:7-8

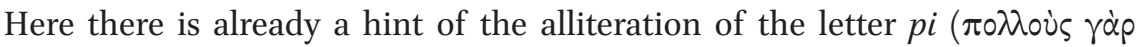
$\dot{\varepsilon} \pi \lambda \dot{\alpha} v \eta \sigma \varepsilon \tau \dot{\alpha} \dot{\varepsilon} v \dot{v} \pi v(\alpha)$, but more noteworthy is the appearance of the verb $\pi \lambda \alpha v \alpha \dot{\alpha} \omega$ meaning to "deceive." The same verb is picked up in the following "wandering" section, but in the middle voice with the meaning "to wander," a more positive sense than in the active. ${ }^{26}$ The verb reappears in v. 11 where the meaning might continue of "wandering," but there is an ambiguity to which we will return. The root of the verb appears again in v. 12 in the noun $\dot{\alpha} \pi \circ \pi \lambda \dot{\alpha} v \eta \sigma ı \zeta$, which is usually understood here as travelling, but as we shall see may reflect a further shift in meaning. Careful associations and mental adjustments have to be made throughout by the reader owing to the literary craft of the passage.

\section{$4 \quad$ Structure and Meaning}

How the interpretation of this passage came to be read as one of travel is unclear. The Old Latin rendering of $\pi \varepsilon \pi \lambda \alpha \nu \eta \mu \varepsilon$ vos as est expertus does not readily lend to such an interpretation, but the translation "travel" is already accepted in the KJV, and is known to commentators in the eighteenth century, ${ }^{27}$

25 Cf. for example, the repetition of $\pi \alpha \iota \delta \varepsilon v \omega$ in Wisdom, representing on the one hand educating (Wis 6:11; cf. 6:25) and on the other punishing (Wis 3:5; 11:9; 12:22). See Ekaterina Matusova, The Meaning of the 'Letter of Aristeas' (in Light of Biblical Interpretation and Grammatical Tradition, and with Reference to its Historical Context), FRLANT 26o (Göttingen: Vandenhoeck and Ruprecht 2015), 65-66, 82-83 on the use of polysemy.

26 On the connections between the dream passage and the rest of chapter 39, see Nuria Calduch-Benages, "Dreams and Folly in Sir 34(31), 1-8," in Auf den Spuren der schriftgelehrten Weisen; Festschrift für Johannes Marböck anlässlich seiner Emeritierung, ed. Irmtraud Fischer, Ursula Rapp, and Johannes Schiller (Berlin: de Gruyter, 2003) 246-47.

27 H. Grotius, Annotationes in Vetus Testamentum. emendatius edidit, et breuibus complurium locorum dilucidationibus auxit Georgius Ioannes Ludou. Vogel, Tomus III (Halae: Apud Io. 
although notably did not appear in the KJV precursor, the Bishop's Bible. ${ }^{28}$ The combination of wandering as a form of experience and of dangers naturally calls to mind travelling in the ancient world. The verb $\pi \lambda \alpha v \alpha \dot{\alpha} \mu \alpha \mathrm{l}$, however, does not convey the sense of travel that has been dominant in scholarship, and indeed is not the most obvious interpretation of the word. Travel would be

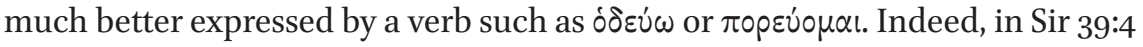
(no Hebrew extant) travelling abroad is expressed, as indicated by the reference to foreign nations, but using a different verb:

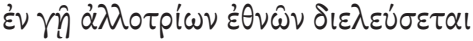

He (the sage) will travel in the land of foreign nations

Instead, $\pi \lambda \alpha v \alpha \dot{\alpha} \mu \alpha$ captures the sense of directionless wandering or being adrift. ${ }^{29}$ It appears this way frequently in Greek, as for example applied to the Thebans when they were trapped in Platea and running around aimlessly looking for a means of escape:

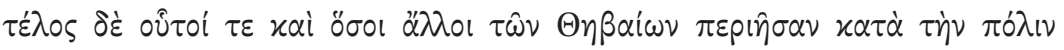
$\pi \lambda \alpha \nu \omega \dot{\mu} \mu \varepsilon v 0$ เ

At length both these and all the rest of the Thebans that were straggling in the city

In the Septuagint $\pi \lambda \alpha v \alpha$ or $\mu \mathrm{l}$ is appropriately used for people wandering in the wilderness (LXX Gen 21:14; 37:15, translating the Hebrew תעה).

A second sense also belongs to the verb $\pi \lambda \alpha v \alpha$ do $\mu \alpha$ of moral drifting, that is erring or being led astray. This meaning again is to be found in classical Greek (e.g., Plato, Phd. 79c) and in the Septuagint. It is appropriately used in LXx Deuteronomy (e.g., 11:28; 13:6; 30:17) in the warning of being led astray by idolatry (Hebrew תעה):

Iac. Curt., 1776), 180 (vir peregrinatus); J. W. Linde, Sententiae Jesu Siracidae graece: textum ad fidem codicum et versionum emendavit et illustravit (Danzig: Sumpt. Ferdinandi Troschelii, 1795), 136.

28 The Bishop's Bible reads in v. 10 "he that erreth causeth much wickednesse" and in v. 11 "when I was yet in errour" (The Holie Bible: conteynyng the Olde Testament and the Newe [London: In povvles Churchyarde by Richarde Iugge, 1568], Apocryphus lxxi).

29 T. Muraoka defines it correctly as "mid. to wander about, not knowing whither heading," but still for Sir 31(34):9 opts for the traditional translation "a widely travelled man" (A Greek-English Lexicon of the Septuagint [Louvain: Peeters, 2009], 560). 


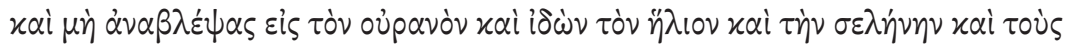

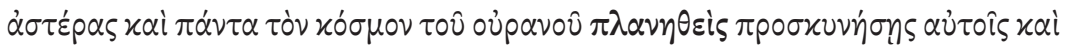

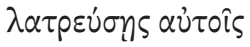

Deut 4:19

And do not, when you look up to the sky and see the sun and the moon and the stars, even any ornament of the sky, be led astray and do obeisance to them and serve them (NETS)

It appears that both senses of $\pi \lambda \alpha v \alpha$ ó $\mu \alpha$ are in play in the ethical context of Sirach's writings where the perfect participle $\pi \varepsilon \pi \lambda \alpha \nu \eta \mu \varepsilon$ vo that we are here dealing with types. In verse 9 it is the type of $\alpha \nu \eta \dot{\rho} \pi \varepsilon \pi \lambda \alpha \nu \eta \mu \varepsilon^{\prime}$ vos that wanders and gains experience and knowledge from such movement. This wandering leads to understanding, and it is clear that the reason for the learning from wandering is that it provides much experience ( $\pi \circ \lambda \dot{v} \pi \varepsilon 1 \rho \circ \varsigma)$. But it is the second sense of the verb that would explain the use in v. 11, especially if we read verses 10 and 11 as a unit, although separated by a verse division in current editions.

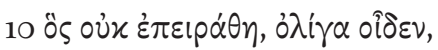

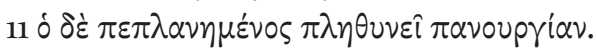

He that is unexperienced, knows little

And he that errs increases trickery

In v. 10 a contrast is drawn between the $\pi \circ \lambda \dot{\pi} \pi \varepsilon p \circ \varsigma$ in v. 9 and the one who knows nothing since he is not experienced ( $\left.\dot{\varepsilon} \pi \varepsilon \varepsilon^{\prime} \alpha \dot{\eta} \eta\right)$. This is the one who wanders in a bad sense (i.e. errs) without learning anything. The verb $\pi \varepsilon ı \alpha^{\alpha} о \mu \alpha l$ in the passive denotes both gaining experience and also being put to the test, which itself would provide experience. The opening of the third line (Sir 31[34]:10) in the pericope draws a clear contrast with the previous two, in describing the person without experience as knowing little. It serves as the antonym of the point made so far, and it makes it likely that in verse 11 this contrast continues. Translations and commentators usually take this line 11 as a continuation of the theme from verse 9 of travelling and a repetition of the sentiment that the one who travels increases his knowledge. It is therefore read as a contrast with 10, rather than a continuation of the thought of verse 10, and is redundant in providing no new information in addition to verse 9 . Thus the NRSV reads "but he that has traveled acquires much cleverness" (cf. NETs; Septuaginta Deutsch "Der jedoch (viel) reist, vermehrt Klugheit"). The discourse marker $\delta \varepsilon$ in this 
interpretation is taken as simple adversative, although often in Greek it has little or no adversative function. It can merely indicate a referent switch, ${ }^{30}$ as here, where it switches from the man with no experience to the man widely experienced. It is a change of topic, but not necessarily a direct contrast.

The idea that verse 11 should be understood negatively is confirmed by the noun $\pi \alpha v o u p \gamma i \alpha$ at the end of the line, even though this has sometimes been taken as a positive term (KJv: "is full of prudence"). It appears from literature that $\pi \alpha v o u p \gamma i \alpha$ was always used in a negative sense of trickery (cf. LSJ 1299 "knavery") and this is how it is to be understood here (cf. Sir 19:23, 25; 21:12). English translations before the NRSV followed the KJV with the meaning "wisdom" and other languages have followed in similar fashion (e.g., German "Wissen”). This positive meaning had already been suggested by Grotius. ${ }^{31}$ The NRSV introduced the translation "cleverness," which has been adopted by NETS and other translations (cf. LXX.D "Klugheit"). This adds a small degree of ambiguity, but it is uncertain how far every translation intended that ambiguity. If it means wisdom or cleverness in a positive sense, it would confirm a continuation of the theme of travelling, and a mere rewording of the opening verse. However, if negative then the verse in Sirach continues a contrast with the person who knows many things - this type of wanderer increases "trickery."

The pericope can therefore be read as describing two types of wandering person. The first type in verse 9 is one who wanders and learns much from his experience. The second type in verse 10 is one who has no experience and therefore knows nothing. The opening words of verse 11 ( $\delta \delta \dot{\varepsilon} \pi \varepsilon \pi \lambda \alpha \nu \eta \mu \varepsilon$ vos) recall v. 9a and at first the reader might think the words again denote the one who wanders. However, the appearance at the end of the line of $\pi \alpha v o u p \gamma i \alpha$ indicates that the line is negative. This is, therefore, the second type of wandering man underlined by a semantic development: $\delta \pi \varepsilon \pi \lambda \alpha \nu \eta \mu \varepsilon$ vos is not only one who wanders but one who errs, and this erring increases trickery. This double meaning of $\pi \lambda \alpha v \alpha \dot{\alpha} \mu \alpha$ is assisted by its use elsewhere in the LXX for departing from the Lord's path to commit wickedness, and is underscored by the repeated use of the verb in Sirach.

30 See Steven E. Runge, Discourse Grammar of the Greek New Testament: A Practical Introduction for Teaching and Exegesis (Peabody, MA: Hendrickson Publishers, 2010), 31. For the most recent discussion of $\delta^{\prime} \varepsilon$ in Koine and the LXX, see Christopher J. Fresch, "Discourse Markers in the Septuagint and early Koine Greek with Special Reference to The Twelve," Unpublished PhD Dissertation (University of Cambridge, 2016), 28-73.

31 Annotationes, 3: 181, where he compares the use of $\pi$ avouprí $\alpha$ for positive words for wisdom in LXX Proverbs. See on this below. 


\section{Homeric Rewriting}

This interpretation of two types of person in Sirach recalls a figure from Greek literature that played a prominent role in Classical and Hellenistic writers. This reminiscence is not incidental, however, since it shapes and accounts for the meaning in Sirach's passage. For the combination of the theme of wandering, discovery, and going astray, along with certain distinct vocabulary choices, render it clear that the Greek text is fashioned on the image of Odysseus. The character of Odysseus is summarized in the opening words of Homer's Odyssey, which encapsulate key features of Odysseus and his experience. ${ }^{32}$ This biographic summary came to fashion in antiquity a varied portrayal of the eponymous hero and his depiction as a literary type. These opening words display literary tropes and themes that we have already seen in Sirach:

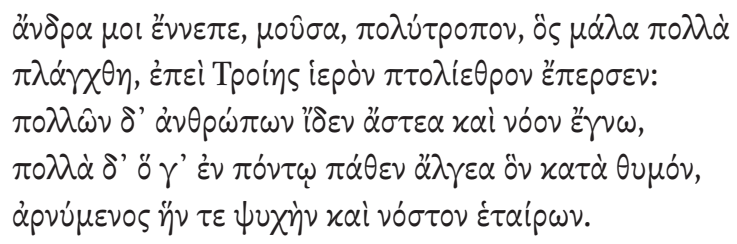

Tell me, Muse, of the man of many ways, who was driven far journeys, after he had sacked Troy's sacred citadel. Many were they whose cities he saw, whose minds he learned of, many the pains he suffered in his spirit on the wide sea, struggling for his own life and the homecoming of his companions. ${ }^{33}$

Od. 1.1-5

At once one may note the alliteration on the letter $p i$ (e.g., $\pi \lambda \dot{\alpha} \gamma \chi \theta \eta, \ldots$

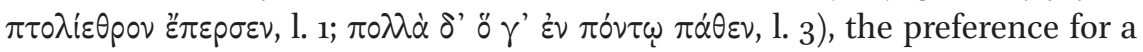
compound form $\pi \circ \lambda \dot{\tau} \tau \rho \circ \pi \circ v$, and the repeated use of the $\pi 0 \lambda$ ú root: $\pi 0 \lambda \dot{\tau} \tau \rho \circ \pi \circ \nu$,

32 This opening of the Odyssey is cited by Calduch-Benages as one of many examples of Greek travel itineraries, but she does not explore any direct connections with Sirach ("Elementos," 295), seeing it as an example of Greek interests in travelling. Middendorp also cited $\mathrm{Od}$.1.1 (Stellung, 11), but he has largely been dismissed by scholars since they nor Middendorp distinguish between the Hebrew and the Greek. See, e.g., Frank Ueberschaer, Weisheit aus der Begegnung: Bildung nach dem Buch Ben Sira, BZAW 379 [Berlin: de Gruyter, 2007], 237 and n. 217. The argument here is that the Odyssey does play a part specifically in the Greek translation but not in the Hebrew, and key to this is that the themes in the reception of the figure of Odysseus are the very ones elaborated in Sirach.

33 Translations of Homer are from Richmond A. Lattimore, The Odyssey of Homer: Translated with an Introduction (New York: Harper \& Row, 1967). 
$\pi 0 \lambda \lambda \dot{\alpha}$ (l. 1); $\pi 0 \lambda \lambda \hat{\omega} \nu$ (l. 3); $\pi 0 \lambda \lambda \dot{\alpha}$ (l. 4). The themes found here of wandering, of seeing and knowing many things, and of encountering sufferings are all to be found in the Ben Sira passage. In Homer's Odyssey the verb used to denote his wandering is the Epic verb $\pi \lambda \dot{\alpha} \zeta \zeta_{\alpha} \alpha$ l (Od.1.2), which also has two connotations of "to go astray" and in the active "to lead astray." The enjambment of line 1 into line 2 reinforces the prominence of this verb. In standard Greek this verb came to be replaced by $\pi \lambda \alpha v \alpha$ ó $\mu \alpha \mathrm{l}$, a verb that has the same range of meanings as $\pi \lambda \dot{\alpha} \zeta o \mu \alpha \mathrm{l}$. Thus, in scholia on Homer and in the ancient lexica $\pi \lambda \dot{\alpha} \zeta{ }_{0} \mu \alpha \mathrm{l}$ is regularly glossed as $\pi \lambda \alpha \nu \alpha \dot{\alpha} \mu \alpha a$ (e.g., Hesychius pi 2427). It is therefore this later verb $\pi \lambda \alpha v \alpha \dot{\alpha} \mu \alpha \mathrm{l}$ that is found in Sirach and that can serve as an allusion to Odysseus.

Other themes from the Odyssey are picked up in Sirach as well. In the opening of the Odyssey we see how knowledge in line 3 is a result of his experiences in lines 1-2. Throughout the Odyssey discovery and experience are closely connected, and lead to knowledge. Curiosity reigns whenever Odysseus lands at a new place and he must seek out to learn more about it. This is clear in arriving at the island of the Cyclops, for example, when he begins to explore the new location:

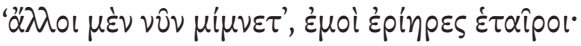

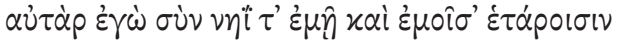

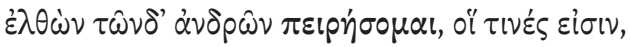

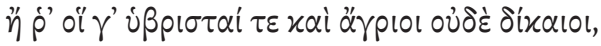

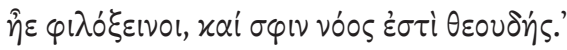

The rest of you who are my eager companions, wait here, while I, with my own ship and companions that are in it, go and find out about these people, and learn what they are whether they are savage and violent, and without justice, or hospitable to strangers and with minds that are godly. Od. $9.172-176$

We may observe that the verb of discovery is $\pi \varepsilon ı \rho^{\circ} \circ \mu \alpha \mathrm{l}$, the same verb used in Sir 31(34):10. It is a verb that can mean to experience but also has the sense of making a trial or putting to the test. This verb becomes ever more frequent in the second half of the Odyssey and could be said to be a leitmotif of the work, as Odysseus gains experience by examining and testing his environment. ${ }^{34}$ As 
Marincola observes, his tales of wandering recall his discoveries as much as the adventures he experienced. ${ }^{35}$

To understand why there would be an allusion in Sirach to the Odysseus story, however, it is not sufficient to consider Homer or to draw comparisons with $\mathrm{Od}$. 1.1-3 alone. Rather, it is the reception of the figure of Odysseus in Classical and Hellenistic literature that finds the greatest parallels to Sirach. As much as the text of Homer itself is important, and the word-play and rhetorical features of the Odyssey are certainly reflected in Sirach, so too is the reception of the figure of Odysseus which shaped later understanding of his character. The Greek of Sirach is as much formed by this popular reception of the figure as by the specific text of the Odyssey.

In the early reception of the Odyssey, the character of Odysseus was seen as ambiguous, saving himself rather than his fellow sailors and using trickery and ruse to achieve his ends. ${ }^{36}$ Accordingly, he is portrayed in negative terms, especially in the Greek tragedians. The meaning of $\pi 0 \lambda \dot{\tau} \tau \rho \circ \pi \circ \varsigma$ "of many ways" in line 1 of the Odyssey is, according to this interpretation, representative of his cunning and ability to invent lies. ${ }^{37}$ Plato's Hippias Minor is a treatise on lying, in which the philosopher devotes some space to discussing the character of

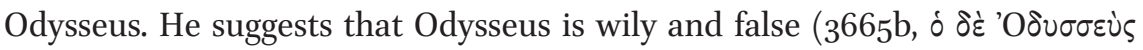

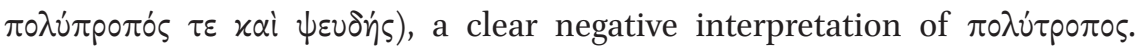
In Sophocles' Philoctetes we have the most extended critique of Odysseus's character. Philoctetes himself knows that Odysseus is bent on cunning argument and wickedness, but does himself finally succumb to similar problems (1111-1112).

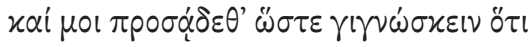

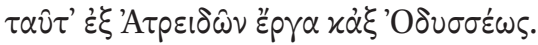

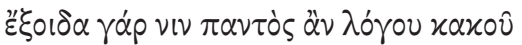

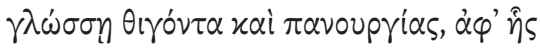

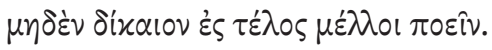

35 John Marincola, "Odysseus and the Historians," Syllecta Classica 18 (2007): 2.

36 Among important studies, see Rutherford, "Philosophy"; Marincola, "Odysseus"; Silvia Montiglio, From Villain to Hero: Odysseus in Ancient Thought (Ann Arbor: University of Michigan Press, 2011); Richard L. Hunter, The Measure of Homer: The Ancient Reception of the Iliad and the Odyssey (Cambridge: Cambridge University Press, 2018).

37 In the most recent translation of Homer the adjective is rendered as "complicated" (Emily R. Wilson, The Odyssey [New York: W. W. Norton, 2017]). 
You are in harmony with me, so that I can recognise that these are the actions of the sons of Atreus and Odysseus! For I know that he lends his tongue to every evil speech and every villainy that can help him compass a dishonest end.

Soph Philoc. $405^{-409^{38}}$

Against this background a competing tradition developed by the late fifth century BCE that presented Odysseus as an ideal model to follow. The wanderings of Odysseus become the model for true investigation both for ancient philosophers and for historians. The experiences and first-hand enquiry when travelling guaranteed that the investigator has sure knowledge. This model of Odysseus as a man learning by his travelling might already be evident in Parmenides ${ }^{39}$ and Plato, but it is most clearly expressed in a fragment of Democritus, where the Homeric wording is picked up distinctly (VS 68 B 299), as recorded in Clement. ${ }^{40}$

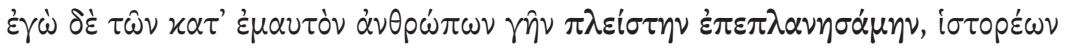

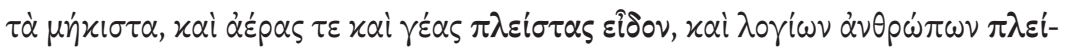

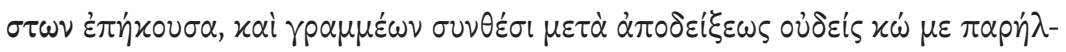

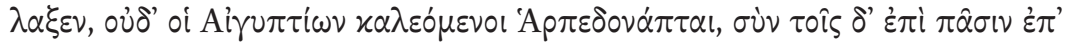

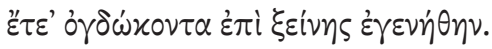

I have travelled most extensively of all men of my time, making the most distant inquiries, and have seen the most climes and lands, and have heard the greatest number of learned men; and no one has ever surpassed me in the composition of treatises with proofs, not even the so-called Arpedonaptae of Egypt; with them I passed eighty years on foreign soil.

For Democritus Odysseus serves as the model of the true investigator, and it is this experience that ensures his writings will surpass others. Democritus uses the verb $\pi \lambda \alpha v \alpha$ do $\mu \alpha$ that appears also in Sirach, and, along with an emphasis on "the most things," the vocabulary here is similar to that of Sirach. Even

38 Translation: Sophocles II, ed. and tr. H. Lloyd-Jones, LCL 21 (Cambridge, MA: Harvard University Press, 1994), 295.

39 Eric A. Havelock, "Parmenides and Odysseus," Harvard Studies in Classical Philology 63 (1958): 133-43.

40 There is some uncertainty over the authorship of the fragment, but this matters little for the argument. 
more so the scholia on $\mathrm{Od}$. 1.3 ("he saw the cities of many men and knew their minds") contrast Odysseus with "fools who see many cities and countries but

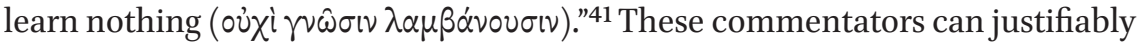
claim that even in Homer itself there is a clear connection between travelling and knowledge. ${ }^{42}$ Telemachus asks Nestor if he had any news learnt by his own

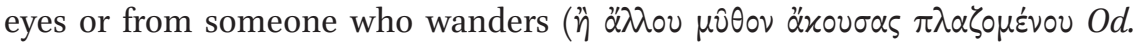
3.92-95), wording that is used again when he comes to Menelaus (Od. 4.32235). Knowledge is also something that Odysseus acquires during his travels, both from his experience and from his meeting with others. The Sirens, who become important in later traditions, are said to know things ('i $\delta \mu \varepsilon v)$ and offer

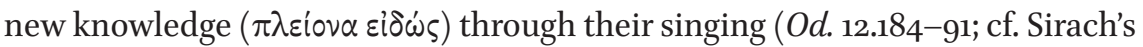

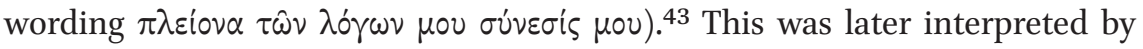
Heraclitus in his Homeric Problems that Odysseus learned from the Sirens as

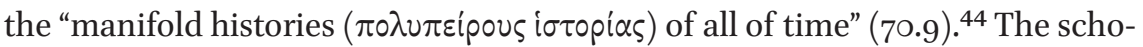
lia also recast the meaning of $\pi \circ \lambda v_{\tau} \tau \rho \pi \circ \varsigma$ as a type of knowledge, but one that can be used for trickery:

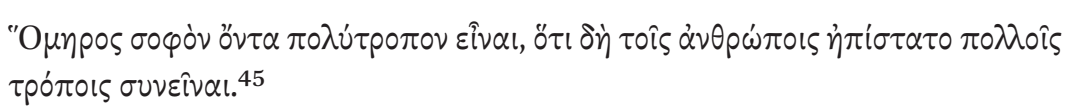
Homer says that one who is wise is polutropos, since he knows how to deceive men by many ways.

The scholia reflect the ambiguous nature of Odysseus's knowledge.

One of the first clear rehabilitations of the character of Odysseus was by Antisthenes, the pupil of Socrates. Of his surviving fragments two rhetorical exercises have been preserved complete, one on Ajax and one on Odysseus that revisit the famous rivalry. In his Odysseus, Antisthenes also expressed

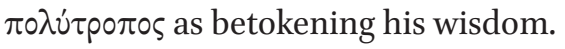

41 Arthur Ludwich, Scholia in Homeri Odysseae A 1-309 auctiora et emendatiora (1888-90; repr. Hildesheim: Georg Olms, 1966), 11.5.

42 S. D. Olson, Blood and Iron: Story and Story-Telling in Homer's Odyssey (Leiden: Brill, 1995), 1-23; Montiglio, Villain, 123-28.

43 See Hunter, Measure of Homer, 199.

44 Hunter, Measure of Homer, 213.

45 Ludwich, Scholia, 9.4-5. 


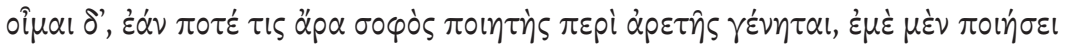

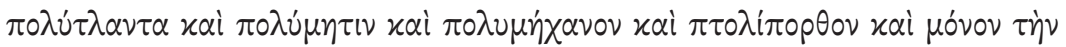

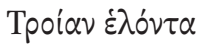

Ant. Od. $14^{46}$

I believe that if ever there be a poet wise on excellence, he would portray me as much enduring and much cunning and much plotting, and a sacker of cities; indeed, the only one to have taken Troy.

Many of the character portraits of Odysseus served the purposes of philosophical groups, especially the Cynics who admired his simple torn clothing, and the Stoics who spoke of his endurance against the temptations of the places he visited. ${ }^{47}$ That it became a more popular trait than only within philosophical circles is seen in how Odysseus becomes the model for historians too. It is here that we find the closest parallels to Sirach's understanding.

The themes of travelling and personal experience are already to be found in Herodotus and Thucydides, and it is possible that Herodotus presents himself as an Odysseus passing through cities of men ( $\alpha \dot{\sigma} \tau \varepsilon \alpha \dot{\alpha} \nu \theta \rho \omega \dot{\omega} \pi \omega \nu$, Hrdt 1.5.3; cf. $\mathrm{Od} 1.3) .{ }^{48}$ Polybius in the second century вСЕ is perhaps the first explicitly to use Odysseus as a model of the historian. ${ }^{49}$ In his discussion of historical method (Polybius 12.27.1-28.5) Polybius quotes the opening of the Odyssey as proof that the best historian is one who has been present and has experience of what he writes.

one has only to pursue one's researches in perfect repose and compare the accounts of different writers without exposing oneself to any hard-

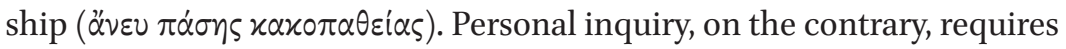
severe labor and great expense, but is exceedingly valuable and is the most important part of history. This is evident from expressions used by historians themselves. [...] Homer has been still more emphatic on this subject than these writers. Wishing to show us what qualities one should possess in order to be a man of action he says:

Tell me, Muse, of the man of many ways, who was driven far journeys Od. 1.1-2

\footnotetext{
46 Text of F. Decleva Caizzi (ed.). Antisthenis fragmenta (Milan: Cisalpino, 1966), frg 15.

47 Montiglio, Villain, 68-69.

48 John L. Moles, "Truth and Untruth in Herodotus and Thucydides," in Lies and Fiction in the Ancient World, ed. C. Gill and T. P. Wiseman (Exeter: Exeter University Press, 1993), 96; Marincola, "Odyssseus," 13-15.

49 Marincola, “Odysseus," 23-24.
} 
and further on-

"Many were they whose cities he saw, whose minds he learned of, many the pains he suffered in his spirit on the wide sea."

Od. 1.3-4 (Polybius 12.27) ${ }^{50}$

Polybius is followed by Diodorus Siculus, who opens his Library of History by praising the experience gained by those writing a universal history, offering

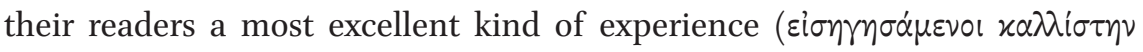
$\xi \mu \pi \varepsilon ı$ íav; $B H$ 1.1.1-2). He proceeds to give a quotation of Odyssey 1.3 as testimony of the learning acquired through experience.

The passage in Sirach can be appropriately interpreted in the light of the growing popularity of Odysseus's travelling as a positive mode of inquiry. There are a number of vocabulary items that are distinctive in this passage as pointing to the Homeric theme. The verb $\pi \lambda \alpha v \alpha$ ó $\mu \alpha$ l as the alternative to $\pi \lambda \dot{\alpha} \zeta o \mu \alpha$ l undoubtedly echoes the wandering of Odysseus, but the ambiguity of the word has already been signalled by the use of the active form for dreams that mislead. As a result in the ethical context there are two types of $\alpha \nu \dot{\eta} \rho \pi \varepsilon \pi \lambda \alpha \nu \eta \mu \varepsilon \dot{v} \circ$ s. This very play on the meaning of $\pi \lambda \alpha v \alpha \dot{\alpha} \mu \alpha \mathrm{l}$ is seen in Plato's early dialogue the Hippias Minor, which provides further confirmation of the association of the verb with Odysseus. The dialogue discusses the character of Odysseus, reaching the conclusion that Odysseus's trickery is better than someone's who behaves unknowingly because Odysseus knew that he behaved falsely. As a result, they conclude with Socratic irony, that the good man is the one who voluntarily performs bad deeds. At this point Hippias admits that that is a conclusion he cannot hold, and Socrates agrees, noting, nevertheless, that it is the logical outcome of their argument. He concludes:

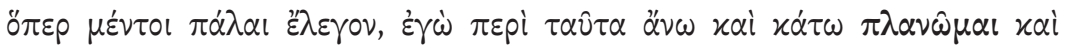

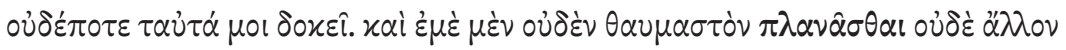

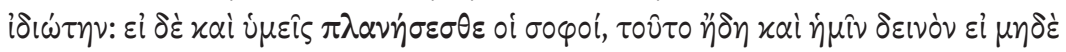

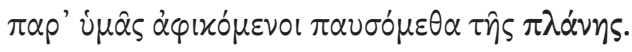

PLATO, Hippias Minor $376 \mathrm{c}$

50 Polybius, The Histories IV, tr. W. R. Paton, rev. F. W. Walbank and C. Habicht, LCL 159 (Cambridge, MA: Harvard University Press, 2011), 447 (with quotations from Homer adapted to Lattimore's). 
however, as I was saying all along, in respect to these matters I go astray, up and down, and never hold the same opinion; and that I, or any other ordinary man, go astray is not surprising; but if you wise men likewise go astray, that is a terrible thing for us also, if even when we have come to you we are not to cease from our straying. ${ }^{51}$

The repeated use of the verb $\pi \lambda \alpha v \alpha$ 'o $\mu \alpha$ l (cf. 372d) and the concluding word (to the whole dialogue!) $\pi \lambda \alpha \dot{\nu} \eta$ can only be an allusion to the Odysseus story, given the focus on Odysseus throughout the dialogue. The vocabulary items operate as a pun since the wandering here is the erring of mistaken reason.

The opening line of the passage in Sirach (31[34]:9a) could be said to be an epitome of the Odyssean fortunes. The verse strikingly opens with ànjp just as Homer opens with $\alpha^{\prime} \nu \delta \rho \alpha$. In similar fashion Hecataeus of Miletus is called an

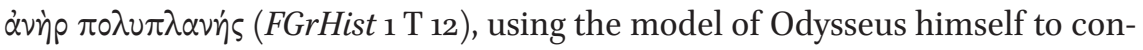
vey the image of man travelling the Mediterranean in his Periegesis. ${ }^{52}$ In Sirach $\alpha \dot{\nu \eta े \rho ~} \pi \varepsilon \pi \lambda \alpha \eta \eta \mu \varepsilon v o \varsigma$ would then serve well as a veiled allusion to Odysseus. This point cannot be taken too far, though, since Sirach often begins charac-

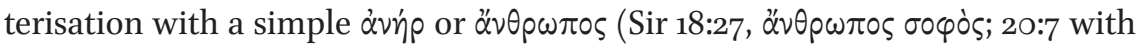

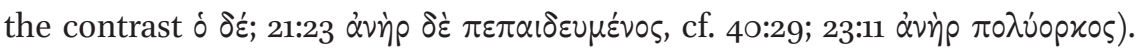
Nevertheless, it is the coincidence with the wording of Homer that is notable in this instance. Meanwhile, the leitmotif of $\pi 0 \lambda \lambda \dot{\alpha}$ from Homer (cf. Od. 1.4) is reproduced in Sirach and है $\gamma \omega \omega$ is the very verb from Homer (Od. 1.3), notably preceding there the adjective $\pi \circ \lambda \lambda \dot{\alpha}$ but separated by a line break. In this one line in Sirach (31[34]:9) the Odyssean experience of learning is reapplied in a

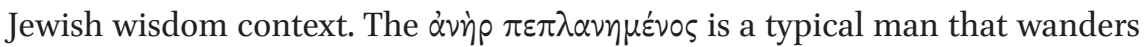
freely, and it is from the experience of wandering that he learns much.

The second line (Sir 31[34]:9b) repeats the sentiment of the first. The figure is described as a $\pi 0 \lambda v i \pi \varepsilon i p o \varsigma$, a word used twice elsewhere in Sirach (21:22; 36:25[22]) but not elsewhere in LXX. In form it echoes the many compound epithets in Homer composed from $\pi 0 \lambda v$ s, including a number of significant ones used of Odysseus: $\pi 0 \lambda \dot{v} \tau \rho \circ \pi \circ \varsigma, \pi \circ \lambda \dot{\mu} \mu \eta \tau \iota \varsigma, \pi \circ \lambda u \mu \eta \dot{\gamma} \alpha \alpha \nu \circ \varsigma, \pi 0 \lambda \dot{\tau} \tau \lambda \alpha \varsigma, \pi \circ \lambda \dot{\tau} \tau \lambda \eta \tau \circ \varsigma$. The association of this particular compound $\pi \circ \lambda v i \varepsilon i p o \varsigma$ with Odysseus is made in Diodorus Siculus. In his opening discussion of how a good historian

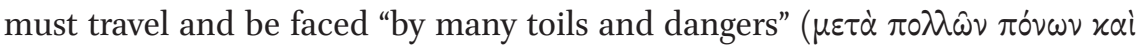

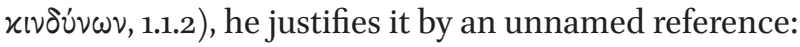

51 Translation: Plato IV, tr. H. N. Fowler, LCL 167 (Cambridge MA: Harvard University Press, 1926), 475 .

52 Marincola, “Odysseus," 8. 


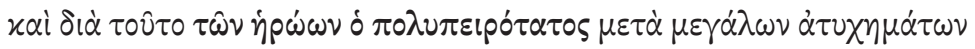

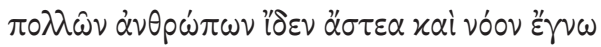

BH 1.1.2

and this is the reason why the most widely experienced of our heroes suffered great misfortunes before he

Of many men the cities saw and learned. ${ }^{53}$

The quotation from Od. 1.3 makes clear, had there been any doubt, that he is here speaking of Odysseus. He is the most experienced of all heroes, owing to the importance of "experiencing" ( $\left.\pi \varepsilon ı \rho^{\alpha} \alpha \mu \alpha \mathrm{l}\right)$ in the Odyssey as a characteristic of Odysseus's travels. It is this experience that leads to his knowledge (the theme in Diodorus's prologue), and accordingly in Sirach the person with much experience is the one who can speak with knowledge. ${ }^{54}$ It is also reminiscent of the scholia where Odysseus becomes है"

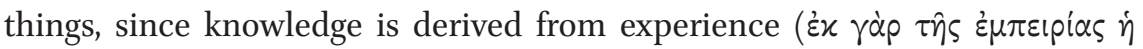

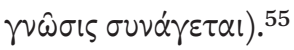

The other distinctive vocabulary choice that can be related to Odysseus is the noun already discussed, $\pi \alpha v o v p \gamma i \alpha$. It appears from literature to have become specifically associated with a negative facet of Odysseus. In Sophocles's Philoctetes, quoted above, the dangers of Odysseus's trickery is expressed by $\pi \alpha v o u p \gamma i \alpha$. Philoctetes repeats it in reference to Neoptolemus who has fallen under the spell of Odysseus's trickery:

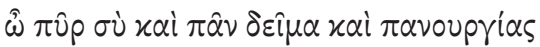

$$
\begin{aligned}
& \delta \varepsilon เ v \hat{\varsigma} \varsigma \tau \dot{\varepsilon} \chi \nu \eta \mu \mu^{\prime} \varepsilon^{\prime \prime} \chi \theta i \sigma \tau 0 \nu \\
& \text { Philoc. 927-928 }
\end{aligned}
$$

You fire, you total horror,

you hateful masterpiece of dire villainy

It is possible too that Euripides in his version of the Philoctetes applies the

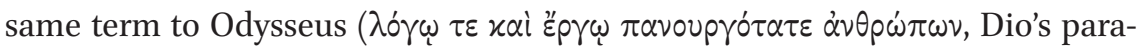
phrase at Or. 59.9). ${ }^{56}$ The term is also used by Plato in the Hippias Minor $365 \mathrm{e}^{57}$

53 Translation: Diodorus of Sicily I, tr. C. H. Oldfather, LCL 279 (Cambridge, MA: Harvard University Press, 1933), 5 .

54 See Rutherford, "Philosophy," 158.

55 Ludwich, Scholia, 10.26.

56 Montigilio, Villain, 171 n. 25; see too the use of $\pi \alpha v \tau o u p \gamma o ́ s$ in Sophocles's Ajax 445.

57 See Montiglio, Villain, $38-39$. 


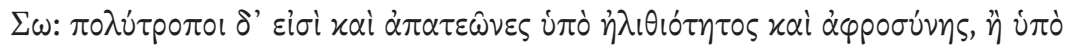

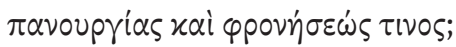

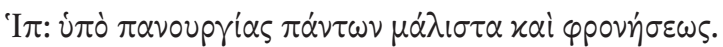

Socrates: But are they wily and deceivers by reason of simplicity and folly, or by reason of shrewdness and a sort of intelligence?

Hippias: By shrewdness, most assuredly, and intelligence.

It is an appropriate term to use of Odysseus as the negative mirror reflection

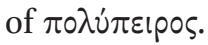

The four lines on wandering, therefore, draw upon the tradition of knowledge gained through experience, as typified by Odysseus. As the passage progresses, however, any sense of physical movement fades into the background as the ethical sense prevails, and the understanding of Odysseus as a type develops.

The autobiographical section is one of a number of first person passages throughout the book of Ben Sira. ${ }^{58}$ The transformation of the vocabulary, already seen in the previous verse, into an ethical ideal is continued in these verses. The author claims access to knowledge since he has seen many things, and he has done this in his $\dot{\alpha} \pi \circ \pi \lambda \dot{\alpha} \nu \eta \sigma ı \zeta$. Interpretations of the word $\dot{\alpha} \pi \circ \pi \lambda \dot{\alpha} \nu \eta \sigma \iota \varsigma$ are usually based on the passage being a personal account of his own travels, and therefore it is rendered by "travels" (NRSV) or "wandering" (NETS; LXX.D "Reise"). Although the root of the noun is $\pi \lambda \alpha v \alpha \omega$, as we have already seen words from this verb convey different senses in each occurrence in the passage. The compound verb $\dot{\alpha} \pi \circ \pi \lambda \alpha v \dot{\alpha} \omega$ in Greek is never used of physical travelling but is rather used of digressing in a narrative (LSJ 213). Likewise, the noun $\dot{\alpha} \pi \circ \pi \lambda \dot{\alpha} \nu \eta \sigma ı \zeta$ is never found of travelling, despite LSJ offering a unique sense of "wandering" to the occurrence in Sirach (LSJ 213). ${ }^{59}$ Rather $\dot{\alpha} \pi \circ \pi \lambda \dot{\alpha} \nu \eta \sigma \zeta$ is first used for a digression in a narrative or argument (Plato Polit. 263c; Aristotle Rhet. $1414 \mathrm{~b}$ ) but then comes to mean a mental distraction. Thus, in the Testament

$5^{8}$ Jan Liesen, "Strategic Self-References in Ben Sira," in Treasures of Wisdom: Studies in Ben Sira and the Book of Wisdom, ed. N. Calduch-Benages and J. Vermeylen, BETL 143 (Leuven: Peeters, 1999), 67.

59 Linde, Sententiae, 156 discusses $\dot{\alpha} \pi \circ \pi \lambda \alpha \dot{\eta \eta} \sigma \varsigma$, but disagrees with Grotius (Annotationes, 181: in peregrinatione) on the sense of travelling. He thinks it means involuntary travelling. 
of Issachar it clearly involves a mental distraction and one that could lead to wrong doing:

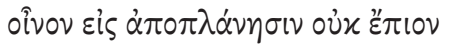

I have not drunk wine to be led astray by it Test. of Issachar 7:3

Sirach therefore is speaking of a period of being diverted from the righteous path, a mental distraction. The literary connection is made by the root $\pi \lambda \alpha \nu \alpha \omega$, but the sense has been transformed. From this experience he has learnt much and therefore his understanding is of more experiences than he can put in words. This connects closely with the previous section (Sir 31[34]:9) through

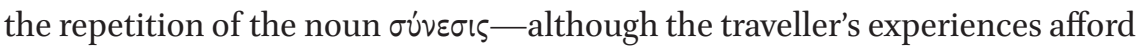
him the ability to speak of his knowledge, as in verse 9 , his experiences are too many to recount and his words do not reflect his full knowledge.

Verse 12 once more picks up an Odyssean theme of both danger and salvation. Dangers are a trope of the Odyssey, as implied in the opening lines $(\mathrm{Od}$. 1.3-5), and become the paradigmatic experience of Odysseus and his sailors throughout the work. Polybius, in the passage already discussed above, uses it effectively to dismiss those who merely read books in libraries, ${ }^{60}$ to contrast such persons to the true historian who must face the dangers to gain knowledge:

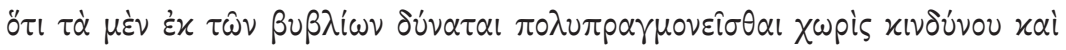

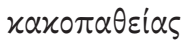

Inquiries from books may be made without any danger or hardship Polybius Hist 12.27.4

Diodorus ( $B H$ 1.1.1-2), who was clearly influenced by Polybius, ${ }^{61}$ offers to provide his readers the knowledge through his writing without those attendant

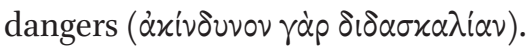

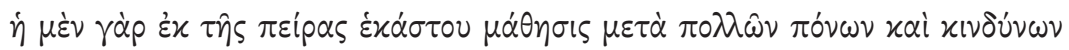

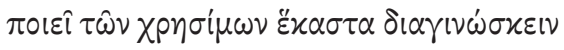

6o Marincola, "Odysseus," 20.

61 Marincola, "Odysseus," 27. 
For ... the learning which is acquired by experience in each separate case, with all the attendant toils and dangers, does indeed enable a man to discern in each instance where utility lies

Diodorus $B H$ 1.1.1

This motif of dangers is again transformed by Sirach, though, into a new understanding of those dangers. Rather than speaking of xivouvol, he encapsulates it

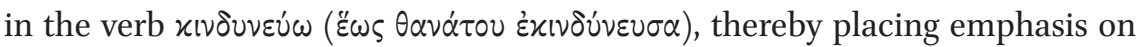
death as the greatest risk. This is the specific danger that Sirach has in mind for his wandering man, and it is one that introduces a theological theme to his narrative. The reference to death leads on to the expression of his being

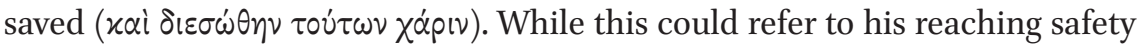
when in dangerous circumstances while travelling, the ethical context and positioning in the book suggest an alternative. The antecedent of the phrase

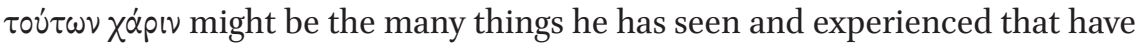
allowed him to be saved. It might, however, equally look forward to the following pericope, which is rarely considered in discussions of this passage. Nevertheless, verbal connections between the two passages have been identified by Calduch-Benages. ${ }^{62}$

In English translations (such as NRSV and NETS) there is a section break between verse 13 and 14, but in recent Greek editions such as the Göttingen edition and Rahlfs' the passage continues until verse 20 (= Rahlfs's v. 17) without a break, as it does in some major codices. It appears that the following passage (Sir 31[34]:14-20), on trusting in the Lord has allowed the translator to develop the Odyssean theme for a theological purpose. As we have seen, he composes first a passage on experience as the ideal form of knowledge, and then a passage on departing from that knowledge as a cause of trickery. These are the dangers that Sirach sees and from which salvation is required.

The continuance of the theme from the wandering section is seen in the first two lines of the passage, Sir 31(34):14-20, through their emphasis on salvation:

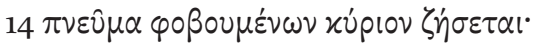

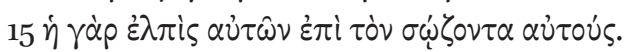

The spirit of people who fear the Lord will live, for their hope is in the one who saves them. (NETS)

62 N. Calduch-Benages, En el crisol de la prueba. Estudio exegético de Sir 2,1-18, Monografías de la Institución San Jerónimo 32 (Estella, Navarra: Verbo Divino, 1997), 200; ead. "Dreams and Folly," 246-47. 
The concern of Sirach's proximity to death is picked up and addressed by the promise that those who fear the Lord will live, and his recognition of being saved is balanced by the designation of God as the one who saves ( $\tau \dot{0} v \sigma \dot{\omega} \zeta o v \tau \alpha)$. There is a clear thematic link between the two passages. The passage proceeds with various images of God as protector drawn from biblical texts, and concludes in words reminiscent of Deut 30:19 and Ps 12:4:

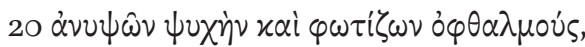

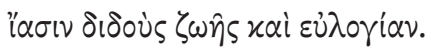

one who uplifts the soul and enlightens eyes, gives healing of life and blessing.

The passage therefore is framed by life offered by God to those who follow him. The theme of saving life is not a departure from the Odyssean theme, but could be termed its pinnacle. ${ }^{63}$ It is already introduced in the opening of the Odyssey:

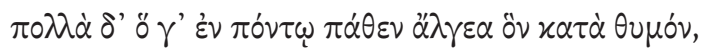

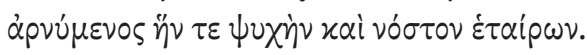

Od. 1.4-5

many the pains he suffered in his spirit on the wide sea struggling for his own life and the homecoming of his companions.

It is expanded upon by Antisthenes (Od. 8-9):

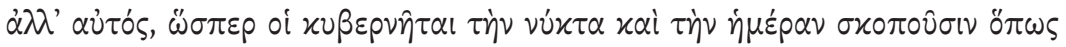

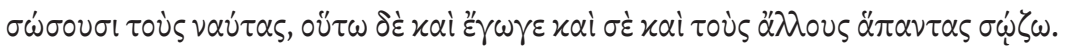

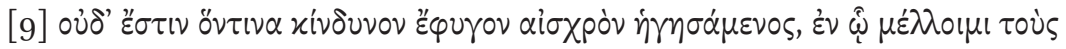

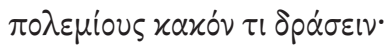

but I myself, just as helmsmen keep watch - through the night and through the day, so that they save the sailors-so I am the one who saves both you and all the others. [9] And there is no danger that I shirked, because I thought it shameful, provided I could do some damage to the enemy.

63 This interpretation of the Odyssey develops in Christian and Neoplatonic traditions. See Jean Pépin, "The Platonic and Christian Ulysses," in Neoplatonism and Christian Thought, ed. Dominic J. O'Meara (Norfolk: International Society for Neoplatonic Studies, 1981), $3^{-18 .}$ 
The translator of Sirach has taken the theme of erring through sin as a danger from which God can deliver, a common theme in Jewish literature of the time. He expresses it most easily through the double meaning of the verb $\pi \lambda \alpha \nu \alpha \dot{\alpha} \mu \alpha \mathrm{l}$. As a sage one can learn through good exploration, since in the manner of Odysseus such wanderings lead to knowledge. While in contrast wandering in the negative sense of erring can lead to wickedness. This is a theme well known from Proverbs and typical of the wisdom tradition (e.g., Prov 22:3; 27:12). As the figure of Odysseus there are therefore many dangers to be encountered in erring but from which one can be saved. The use of the Odyssean theme draws out the meaning more sharply, especially emphasizing the role of knowledge as a sapiential component and the dangers of moral wandering.

The Hebrew Vorlage

The fact that no Hebrew text of Ben Sira has been preserved might appear to be a major obstacle in determining interpretation on the part of the translator. However, as has been demonstrated, the Greek displays inner-Greek allusions that must be independent of any Hebrew source. Word-plays across the passage and specific vocabulary associated with the figure of Odysseus suggest an interpretation on the part of the translator that would not have been possible in a Hebrew version. It is a reasonable assumption that the Hebrew verb behind Greek $\pi \lambda \alpha \nu \alpha$ do $\mu \alpha$ Is is lead" (e.g., Jer 23:13) and "to wander" (e.g., Gen 21:14), and it is the verb used in Sir 51:13 (11QPs $\left.{ }^{a}\right){ }^{64}$ This Hebrew verb is regularly translated by the Greek verb in the LXX (e.g., Gen 37:15; Exod 23:4; cf. Sir 3:24) and therefore it would have been the basis for the translator's choice of the verb $\pi \lambda \alpha v \alpha$ do $\mu \alpha$ l. Likewise, the

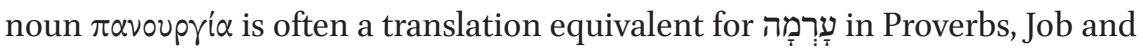
Sirach and therefore the likely equivalent here. The translator had the ability to choose lexical equivalents for each word in his Vorlage, and yet be creative in the meaning of the passage.

However, when comparison is made with the Syriac a number of differences may be noted (here underlined), suggesting the Hebrew Vorlage may have not been precisely represented by the Greek. ${ }^{65}$

64 See too Marböck, Weisheit, 161.

65 The text is quoted from Núria Calduch-Benages, Joan Ferrer and Jan Liesen, La sabiduría del escribe. Wisdom of the Scribe: Edición diplomática de la Peshitta del libro de Ben Sira según el Códice Ambrosiano, con traducción española e inglesa. Diplomatic Edition of the Peshitta of the Book of Ben Sira according to Codex Ambrosianus, with Translations in 


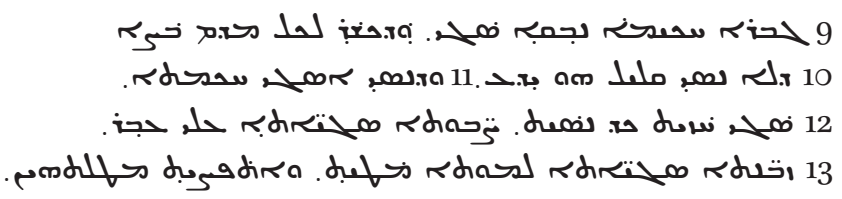

9 A wise man will explore much, And he who is diligent inquires into everything. $10 \mathrm{He}$ who is not tested knows little, 11 and he who is tested has increased wisdom, 12 Much I have seen when I tested (them), and many things have befallen me. ${ }^{66} 13$ Many times I have reached death, and I was delivered because of them.

It has been well established that the Syriac version of Ben Sira is for the most part a translation of the Hebrew, although it should be recognized that it is not identical to the Hebrew witnesses. ${ }^{67}$ One of the changes that van Peursen identifies is the Syriac tendency to repeat words or phrases where the Hebrew has different words, thereby strengthening textual cohesion and producing repetitive parallelism typical of the Aramaic-Syriac poetic tradition. ${ }^{68}$ One case that he identifies is here in Sir 31(34):10-12 where sael occurs three times, corresponding to three different words in Greek. ${ }^{69}$ The problem though is that the Greek itself also has a tendency to vary its vocabulary, and here with good intent. We cannot be sure that the Syriac has deviated from its Hebrew Vorlage in this case, and it remains a possibility that both have deviated in different ways.

The Syriac suggests that testing and the wisdom that comes from the test were the central themes behind these verses, just as it is a common theme elsewhere in Ben Sira. ${ }^{70}$ One can see that the Syriac implies a Vorlage that was close

Spanish and English, 2nd ed., Biblioteca Midrásica 26 (Estella, Navarra: Editorial Verbo Divino, 2015).

66 Marböck (Weisheit, 161) suggests the Syriac is a better translation than the Greek here.

67 W.Th. van Peursen, Language and Interpretation in the Syriac Text of Ben Sira:A Comparative Linguistic and Literary Study, Monographs of the Peshițta Institute, Leiden 16 (Leiden: Brill, 2007), 16-18, makes the sensible point that for the Syriac to match the Hebrew would require no changes to text throughout history, that the translation must be entirely literal and consistent, and that the status of Sirach in the Syriac church would have had no affect on it. His monograph shows that this is not the case. For a helpful overview of approaches to the Syriac, see Franz Böhmisch, "Die Vorlage der syrischen Sirachübersetzung und die gereimte hebräische Paraphrase zu Ben Sira aus der Ben-Ezra-Geniza," in Texts and Contexts of the Book of Sirach / Texte und Kontexte des Sirachbuches, ed. Gerhard Karner, Frank Ueberschaer, and Burkard M. Zapff, sCs 66 (Atlanta, GA: SBL Press, 2017), 199-201.

68 Van Peursen, Language, 63.

69 Van Peursen, Language, 66.

70 See especially Calduch-Benages, En el crisol. 
to the Vorlage of the Greek, with each word in Greek having an equivalent in its source. Nevertheless, from the Syriac we may identify some of the key terms that were likely present in the Hebrew Vorlage and how the Greek has chosen to render them. The verb נow is the same used in the Peshitta for Abraham's paradigmatic test (Gen 22:1, Hebrew נסה). It appears frequently in Ben Sira and

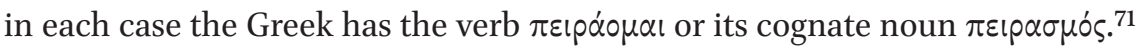
The Hebrew equivalent, where it is extant, is in every case the verb נסה or the noun נסיון. The Syriac could be translated as to experience as well as to test, since being tested entails undergoing an experience. ${ }^{72}$ This semantic range applies as well to $\pi \varepsilon i p \alpha \dot{\alpha} \mu \alpha$. The testing would naturally have suggested the

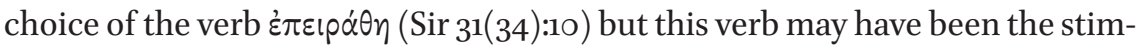
ulus for the Homeric rewriting. As a result, the translator has also introduced the concept of "experience" in the adjective $\pi 0 \lambda \dot{u} \pi \varepsilon i p o s$ (v. 9), where the Syriac "to be diligent" (טשi) implies the Hebrew contained the verb כשר "to succeed" (cf. Sir 13:4).

Another deviation in the Greek seems likely with the introduction of the idea of wandering and learning in verses 9-10, which are the very themes from Homer. This is further developed in v. 11 by wandering in the ethical sense $(\dot{\alpha} \pi \circ \pi \lambda \dot{\alpha} \nu \eta \sigma \iota \varsigma)$ instead of testing. By contrast in the Syriac of verse 9 we find a different word for "to test," جمر Peal, which can also mean "to search."73 This verb appears 11 times in the Syriac of Ben Sira, twice with the Hebrew equivalent בחקר "to explore" (11:7, 28), and once with "to try" (34[31]:26), ביץ hitpolel

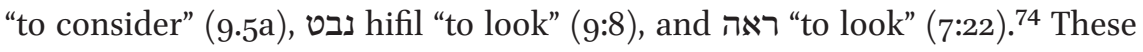
Hebrew verbs, and especially חקר "to explore" $(11: 7,28)$ and "to try," are typical of the wisdom activity (e.g., חקר in Job 28:3, 27; 32:11; Eccl 12:9 [Piel]; איש חכם in Job 12:11; Prov 17:3). From the Syriac we may reconstruct 9a as

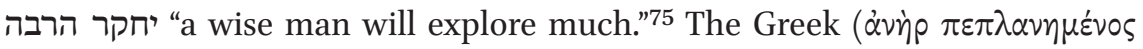
$\varepsilon " \gamma v \omega \pi 0 \lambda \lambda \dot{\alpha}$ ) preserves an equivalent for each word, but reverses the structure so that rather than a wise man, we have a man that wanders (an interpretation

71 For equivalents of Syriac, see Calduch-Benages, En el crisol, 50-51.

72 Michael Sokoloff, A Syriac Lexicon: A Translation from the Latin. Correction, Expansion, and Update of C. Brockelmann's Lexicon syriacum (Piscataway, NJ: Gorgias Press, 20o9), 925. This is the translation given by Calduch-Benages et al., La sabiduría, 212.

73 Sokoloff, Syriac Lexicon, 176.

74 We are reliant on Michael M. Winter, A Concordance to the Peshittta Version of Ben Sira, Monographs of the Peshițta Institute Leiden 2 (Leiden: Brill, 1976).

75 Moses Z. Segal, The Complete Book of Ben Sira [in Hebrew], 3rd ed. (Jerusalem: Bialik Institute, 1972) has reconstructed the Hebrew text but he follows closely the Greek in this passage, which means we can only partially follow his lead. 
of exploring), and instead of exploring, that wanderer knows much (an interpretation of his being wise).

In verse 11 the theme of testing is again replaced by wandering in Greek, and the noun "wisdom" (שحدר); Hebrew likely reconstructed as חכמה) is replaced by $\pi \alpha v o u p \gamma i \alpha$. The translator has taken licence from Lxx Proverbs, where $\pi$ avoûpyos is used in a positive sense and serves as an equivalent for the adjec-

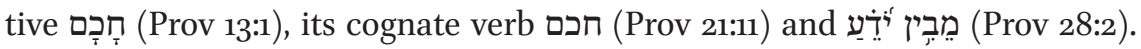
This probably arose from the fact that עָרָמָה (regular equivalents for $\pi \alpha v 0 u p \gamma \gamma \varsigma \varsigma$ and $\pi \alpha v o u p \gamma i \alpha$ ) take on a positive sense in Late Biblical Hebrew (cf. the equivalent ouvetós at Prov 12:23). ${ }^{76}$ The point here is that the Sirach translator preserved an equivalence from Proverbs, but deftly maintained the original negative Greek sense to continue the Odyssean theme. From this it can be deduced that the translator maintained a quantitative word equivalence to his Hebrew Vorlage, but varied his word choice to create the subtle senses he intended. ${ }^{77}$

\section{Other "Travel Passages" in Sirach}

The interpretation of $\operatorname{Sir} 31(34)$ as travel is usually bolstered by other references to the travelling sage in Ben Sira. One case that is often cited, Sir 51:13, might well be the reason for the translator's developing his theme in Sir 31(34), but by adopting the notion of erring from there and not that of travelling. The passages are very similar since 51:1-12 is a prayer for salvation, including the statement that the speaker came close to death (Sir 51:6, MS B):

ותגע למות נפשי וחיתי לשאול תחתיות:

My soul touched death and my life Sheol below

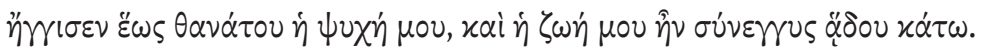

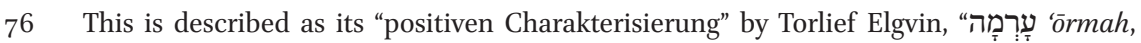
II," in Theologisches Wörterbuch zu den Qumrantexten, ed. H.-J. Fabry and U. Dahmen (Stuttgart: Kohlhammer, 2011-16), III, 218.

See Aitken, "Literary and Linguistic," 118-19, on varying word choice. 
This resembles the wording of Sir 31(34):13. There the prayer for salvation follows the recognition of the speaker's wandering but here it leads on to a new section which begins with the recognition of wandering: ${ }^{78}$

\section{Q5: אני נער בטרם תעיתי ובקשתיה:}

While I was young before I wandered, I sought her

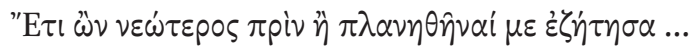

Both the Hebrew (from ${ }_{11} Q_{5}$ ) and the Greek have often been taken to refer to Ben Sira's travels, with the implication that in his youth he had not yet begun his travelling. ${ }^{79}$ This has led to the rendering of the NRSV, "While I was still young, before I went on my travels." More likely is the suggestion by Corley that the poem reflects the last line of Psalm 119 where the theme of wandering

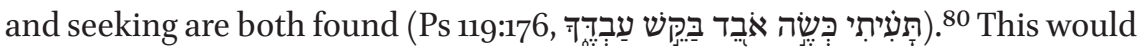
imply the theme is very much that of erring, being distant from the Lord's commands. Sanders in his edition of the Psalms scroll rightly renders the Hebrew verb in Sir 51:13 as "erred." ${ }^{81}$ He observes that the Greek is a good rendering of the Hebrew, but suggests that once the poem was attached to Ben Sira it lost its original significance and took on a connotation in reference to Ben Sira's travels, comparing Sir 31(34):9. ${ }^{82}$ This last step is not necessary if our interpretation of Sir 31(34) is correct. Rather, this theme of wandering in an ethical sense, connected so strongly in Sirach $5^{1}$ with a prayer for deliverance, may have

78 The Hebrew of MS B has a different reading, which can be explained by copyist errors (MS B: אני נער הייתי).

79 See too Solomon Schechter and Charles Taylor, eds, The Wisdom of Ben Sira: Portions of the Book Ecclesiasticus from Hebrew Manuscripts in the Cairo Genizah Collection Presented to the University of Cambridge by the Editors (Cambridge: Cambridge University Press, 1899), LXxx; Smend, Weisheit, 495; G. H. Box and W. O. E. Oesterley, "Sirach," in APOT, 1: 515.

8o See Jeremy Corley, "Ben Sira's Hebrew Poetry in Comparison with the Psalter," in Discovering, Deciphering and Dissenting: Ben Sira Manuscripts after 120 Years, ed. J. K. Aitken, R. Egger-Wenzel, and S. C. Reif, DCLY 2018 (Berlin: de Gruyter), forthcoming.

81 James A. Sanders, Discoveries in the Judaean Desert. 4: Psalms Scroll of Qumrân Cave 11 $\left({ }_{11 Q P s^{a}}{ }^{a}\right.$ (Oxford: Clarendon Press, 1965), 81. He is followed by Skehan and Di Lella, Wisdom, 574 .

82 (Psalms Scroll, 83). He shows how the early versions are partly interpretive translations (Psalms Scroll, 85). For a similar reading of the Hebrew and Greek, see Eric D. Reymond, New Idioms within Old: Poetry and Parallelism in the non-Masoretic Poems of ${ }_{11} Q_{5}\left(={ }_{11} Q_{P}{ }^{a}\right)$, EJL 31 (Atlanta, GA: SBL 2011), 30. 
influenced the translator's interpretation of Sir 31(34). From this the Homeric analogy could have been developed.

A second example of travel is in the depiction of the sage in chapter 39. The Hebrew is once more no longer extant, but the meaning of travel seems to be clear from the context and wording.

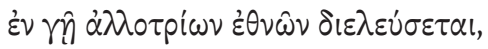

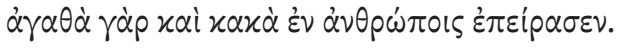

Sir 39:4

He will travel in the land of foreign nations, for he has tested the good and bad things in people. (NETS)

The Greek does not use the verb $\pi \lambda \alpha \nu \alpha \dot{\alpha} \mu \alpha$ l but rather $\delta$ เ $p X o \mu \alpha l$, which is a far better choice for travel and supported by the Syriac $u$ m. The concept of testing does appear again ( $\pi \varepsilon i p \dot{\alpha} \zeta \omega ;$ Syr tween travel and the test. This in fact indicates that this passage is much more than about travel, but about the experience it brings.

The other proposed passage on travel is on the theme of begging (29:21-28). ${ }^{83}$ The beggar is presented as going from house to house looking for charity and

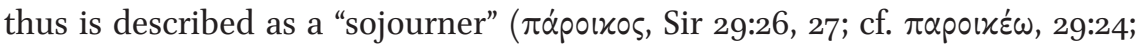
$\pi \alpha p o i x i \alpha, 29: 23)$. It is a metaphor and not to be taken as a record of travel. It does, nonetheless, highlight the fact that when speaking of travel, other terms were preferred to $\pi \lambda \alpha \nu \alpha \dot{\alpha} \mu \alpha$.

10

\section{Conclusion}

In the passage under discussion we find the first extended narrative use of a classical theme in a Jewish translation. Any doubt that this is a subtle allusion to Odysseus should be dispelled by each vocabulary item and each element having significance to the theme. The development of the image accounts for various elements and even the structuring and positioning of the passage.

It is notable that frequently in the history of scholarship Homer has been cited as a comparative case study. As early as Joachim Camerarius in the sixteenth century the praise of learning through experience (peritia) was likened

83 Beentjes, "Concept of Brother," 84. 
to Ulysses, ${ }^{84}$ while Grotius quoted $O d 1.1-3$ as an illustration of the wandering man (along with Horace, Sophocles and Euripides) ${ }^{85}$ Similarly, in recent years Calduch-Benages has cited $\mathrm{Od}_{1.1-3}$ as one of many examples of an interest in travel in antiquity. ${ }^{86}$ Some have also referred to verse $12\left(\pi \lambda \varepsilon^{\prime}\right.$ iov $\alpha \tau \hat{\omega} \nu \lambda{ }^{\circ} \gamma \omega \nu$

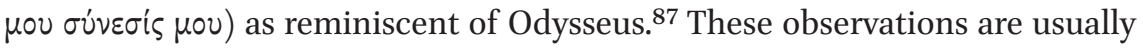
framed as comparative examples, while the only scholar, however, to have suggested a direct influence is Middendorp. He notes some verbal parallels and suggests that Ben Sira might have travelled with a Chrestomathy of Greek literature so that he could allude to the Odyssey. The problem though with Middendorp is that he finds so many classical allusions in Ben Sira that his overall argument is unconvincing. ${ }^{88}$ It has been roundly rejected by scholars, who prefer to see this as an expression of real experience or an internal Jewish development. ${ }^{89}$ What they have failed to recognize is the strength of the verbal associations with Odysseus in the classical tradition and how the themes are so well intertwined in the passage. Also they fail to distinguish between the author Ben Sira and the contribution made by his grandson translator, since it seems to be a shaping by the translator and not original to the Hebrew. The prevalence of Homer in Greek education need hardly be justified to recognize that anyone trained in Greek would have had some preliminary knowledge of the books.

It appears then that the translator was familiar with the reception history of the figure of Odysseus and adapted a Hebrew version that we are not able to reconstruct with absolute certainty. If the Peshitta is anything to judge by, the Hebrew contained a narrative on testing, which would fit in with classical Jewish notions. The Greek adapts this notion in a remarkable way. The legendary wisdom of Odysseus gained from his travels becomes the wisdom of the Jewish sage, who experiences much in the manner of Odysseus. It is such wisdom that distinguishes him from the wanderer who generates trickery or craftiness. While Odysseus is not named, the character type is explicit in the text and this Odysseus type was so well-known that Polybius also did not need to

84 Joachim Camerarius, Sententiae Iesu Siracidae, graece summa diligentia et studio singulari editae, cum necessariis notationibus (Lipsiae, [n.p.] 1568), 223.

85 Annotationes, 3: 180.

86 Calduch-Benages, "Elementos," 295.

87 E.g., Peters, Buch, 282.

88 See H. V. Kieweler, Ben Sira zwischen Judentum und Hellenismus, BEAT 30 (Frankfurt am Main: P. Lang, 1992), 96-105, for discussion of all the Odyssey references drawn up by Middendorp.

89 Frank Ueberschaer, Weisheit, $236-37$. Kieweler is emphatic: "Ben Sira ist Jude und denkt als Jude" (Ben Sira, 104). 
name him. The Odyssean theme coheres well with Jewish theology and therefore is developed into one of salvation from dangers through trust in the Lord.

There are some significant consequences arising from this interpretation of the passage. First, this is a sophisticated blending of a classical trope with Jewish themes. Indeed, the classical theme of Odysseus's wanderings enhances the Jewish themes and draws out more clearly the message. It enables the author to develop the double meaning already existing in Hebrew in the verb "to wander," and through that expand the notions of the wise man and the significance of his hope in God.

Second, this is the first example identified of an extended classical motif blended within a translation of a Hebrew work. It is more than a phrase or an image, which have naturally already been noted, but an interconnected set of themes. Although it is to be expected that cultural reference and language cohere, and Jews learning to write Greek had no option but to learn by the same methods as Greeks, ${ }^{90}$ it is an important illustration of this. We cannot be certain that other translators had this level of knowledge, ${ }^{91}$ but it is likely that all would have had the basic education that included reading Homer. The difference is that only the Sirach translator applied this translation method. In his case, and this is of historical importance, the translator by his own attestation came to Egypt in the second century BCE, perhaps from Palestine. Even someone who does not appear to have been born in the diaspora but grew up in Palestine, has a sophisticated command of Greek and a knowledge of Greek literary traditions. It can be noted that we already find in the Greek Pentateuch some possible knowledge of Homeric features, including the use of the optative and Homeric phraseology such as in Gen 49:26. ${ }^{92}$

Third, since this passage on wandering is a metaphorical narrative on true knowledge and error, it appears doubtful how much of Ben Sira's biography is to be derived from it. It certainly is not to be taken as a passage on travel, a topic that does appear in Sir 39:4 but using a different verb. Sir 51:3 is also to be doubted as a passage about travel. This would accord with recent revisiting of

$90 \quad$ Cf. Jan Joosten, "The Vocabulary of the Septuagint," in Septuagint Vocabulary: Pre-history, Usage, Reception, ed. Eberhard Bons and Jan Joosten (Atlanta, GA: Society of Biblical Literature, 2011), 9.

91 The education surely meant they had some knowledge of Greek literature, and it is inconceivable that they had "little or no familiarity" (so Joosten, "Vocabulary," 3).

92 Trevor V. Evans, "The Comparative Optative: A Homeric Reminiscence in the Greek Pentateuch?" VT 49 (1999): 487-504.; James K. Aitken, "The Language of the Septuagint and Jewish Greek Identity," in The Jewish-Greek Tradition in Antiquity and the Byzantine Empire, ed. J. K. Aitken and J. Carleton Paget (Cambridge: Cambridge University Press, 2014), 129-30. 
the figure of Ben Sira and the notion of ancient authorship. ${ }^{93}$ Instead, the apparently autobiographical elements are there to express a theology rather than to tell us about the real-life sage.

Finally, Greek Sirach contributes to the history of the reception of the Odyssey. Not only is it a further example of the interpretation of Odysseus in a positive sense, but it is early evidence of the connection with salvation. The neoplatonic and Christian adoption of this image has a much longer ancestry than one might expect, and should be explored further. In sum, the passage demonstrates a Palestinian Jew at home in Greek language and culture. It represents the transformation of a Jewish theme the moment it is transposed into Greek, and how that theme is elucidated, clarified and reinterpreted with knowledge of Greek literary tradition. One may wonder whether elsewhere in Sirach similar rewritings appear. It is possible that the translator is more creative than previously thought, but it need not be assumed that there are many such elaborate rewritings. The coincidence of themes in this passage afforded the opportunity for the translator to rewrite his source, while still staying close to a word-for-word equivalence. His willingness to adapt, nevertheless, throws into new light his apologetic preface that there is to be found in his translation

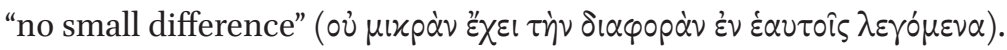

\section{Acknowledgements}

Versions of this paper have been presented at Cambridge, Moscow, Oxford, and Tübingen, and I benefited from the many participants in the discussion. Particular thanks for assistance are due to Ekaterina Matusova for discussion of the argument, and to Srecko Koralija for discussion of the Syriac.

93 See Eva Mroczek, The Literary Imagination in Jewish Antiquity (New York: Oxford University Press, 2016), 86-107. This was further questioned in a co-authored paper by Mroczek and Benjamin Wright (“Ben Sira's Pseudo-Pseudepigraphy: Ideal Authors and Characters from Antiquity to the Middle Ages") presented at the conference "The Pursuit of Wisdom and Human Flourishing: A Virginia Conference on the Book of Sirach and its Contexts" (July 10-12, 2017). 